\title{
Layered $\mathrm{Nb}$-REE ores in the Tomtor Complex (Arctic Siberia): Formation conditions
}

\author{
Elena Lazareva ${ }^{1, *}$, Sergey Zhmodik ${ }^{1}$, Nikolay Dobretsov ${ }^{2}$, Alexander Tolstov ${ }^{3}$, Nikolay \\ Karmanov $^{1}$, Andrey Dar'in ${ }^{1}$, and Ivan Kirichenko ${ }^{1}$ \\ ${ }^{1}$ VS Sobolev Institute of Geology and Mineralogy SB RAS, pr. Akademika Koptyuga 3, 630090, \\ Novosibirsk \\ ${ }^{2}$ A.A. Trofimuk Institute of Petroleum Geology and Geophysics SB RAS, pr. Akademika Koptyuga 3, \\ 630090, Novosibirsk \\ ${ }^{3}$ Research Geological Enterprise (NIGP), Alrosa PJSC, Chernyshevskoye Highway 16, 678170, \\ Mirny, Sakha (Yakutia)
}

\begin{abstract}
We study a unique deposit of Nb-REE ores that occur as three orebodies overlying weathered rocks of the Tomtor ultramafic alkaline-carbonatite complex in the northern Sakha Republic (Yakutia). The formation conditions of the rich Tomtor ores remain poorly constrained. Our hypothesis is that these ores, composed of detrital and authigenic minerals, were deposited in a hydrothermal lake. The Eh-pH parameters of water are reconstructed from REE distribution in ores and in monazite, with reference to results of thermodynamic calculations. The stability fields of hydrous $\mathrm{Ce}, \mathrm{La}$, and $\mathrm{Nd}$ phosphates in the Pourbaix diagrams are proximal in a region within a small range of $\mathrm{pH}(4-6)$ and $\mathrm{Eh}(-0.25-+0.25 \mathrm{~V})$. Monazite apparently formed by dehydration of the precursor phase of hydrous REE phosphate. This inference is supported by coexistence of $\mathrm{Fe}^{3+}$ and $\mathrm{Fe}^{2+}$ minerals.
\end{abstract}

\section{Introduction}

The unique Nb-REE deposit is located within the Tomtor complex of ultramafic alkaline and carbonatite rocks in the northern Sakha Republic (Yakutia) [1-6]. Ores reside in three layers (Severny, Yuzhny, and Buranny sites) [7] which fill depressions in subsided profiles of weathered carbonatites. According to previous studies [7], the rich ore material formed in supergene conditions, as indicated by entrained plant remnants. The size of ore particles $(80 \%<20 \mu \mathrm{m})$ indicates hydrochemical precipitation in most cases. In support of previous results [8], we infer that the ores are lacustrine deposits composed of detrital minerals transported from the Tomtor complex (pyrochlore, Ti oxides, quartz, etc.) and authigenic chemically precipitated phases (monazite, crandallite-group minerals, goethite, etc.) [7]. In typical rich ores, fine grains of monazite, crandallite-group minerals, and

*Corresponding author: lazareva@igm.nsc.ru 
goethite make up a layered structure, with well pronounced layers that are locally no thicker than $20 \mu \mathrm{m}$; the fine-grained mass encloses grains of pyrochlore or Ti oxides. Monazite is the main phase in both $\mathrm{Nb}-\mathrm{REE}$ ores and weathered rocks. In the ores, it occurs as exotic biomorphic aggregates or rarely as submicron crystals. At the Buranny site, it exists as nanometer particles $(\sim 50 \mathrm{~nm})$, which form a dense coat over halloysite tubes $(800-3000$ $\mathrm{nm}$ long, $300 \mathrm{~nm}$ in diameter) and biomorphic aggregates [7]. Monazites in rocks from the Severny and Yuzhny sites are morphologically similar. REE are known to be indicators of various processes and redox parameters. The formation conditions of the rich Tomtor ores remain poorly constrained. We reconstruct those conditions from data on REE distribution in ore and monazite samples and from thermodynamic calculations.

\subsection{Methods}

The distribution of elements in the Tomtor layered ores was analyzed by nondestructive Xray fluorescence with synchrotron radiation (SR-XRF) spectrometry at the Siberian Synchrotron and Terahertz Radiation Centre (SSTRC) of the Budker Institute of Nuclear Physics (Novosibirsk). High-resolution scanning was performed across layering at every $0.2 \mathrm{~mm}$ on a VEPP-3 spectrometer [9]. The results were compared with ore mineralogy data. The composition and morphology of monazite were studied at the Analytical Center of IGM (Novosibirsk) on a Tescan MIRA $3 L M U$ scanning electron microscope with Oxford Instruments Nanoanalysis Aztec Energy/INCA Energy 450+ XMax 80 and INCA Wave 500 analyzers, which are applicable to nanometer particles. The possibility for the formation of REE phosphates and Fe-minerals was illustrated with Eh-pH diagrams using the 7.1 HSC software. Thermodynamic calculations were performed using data from the 7.1 $H S C$ database [10], following the principles detailed in previous publications [11, 12].

\section{Results and discussion}

The first large research of the morphology and composition of the Tomtor ores was carried out for samples from the Buranny site [7]. The analyzed monazites plot within a small field in the Ce-La-Nd diagram (Fig. 1B), with a variable Ce content and almost invariable relative contents of $\mathrm{La}$ and $\mathrm{Nd}$. Further studies showed considerable variations in the CeLa-Nd proportions in some samples (Fig. 1B), such as ores from the Yuzhny site (borehole 308). The Yuzhny samples consist mainly of crandallite-group minerals; monazite (and/or) rhabdophane; Ti oxides with minor $\mathrm{Fe}$ and $\mathrm{Nb}$; a few grains of apatite, pyrite, sphalerite, and galena; as well as minor amounts of kaolinite, muscovite, pyrochlore, and quartz. REE oxides are $0.49 \% \mathrm{Nb}_{2} \mathrm{O}_{5}$ (impurity in Ti oxides), $10 \% \mathrm{REE}_{2} \mathrm{O}_{3}$, and $0.19 \% \mathrm{Y}_{2} \mathrm{O}_{3}$.

The groundmass is composed of thin layers of abundant monazite coexisting with goethite or crandallite-group minerals. Layers of detrital material (most often coarse rutiles up to $1 \mathrm{~mm}$ ) stand out by high $\mathrm{Ti}$ and $\mathrm{Nb}$ in the scanning profiles (Fig. 1A). There are also pyrite segregations (Fe peaks) and rhodochrosite layers (Mn peaks). Ce and La locally behave in a similar way but are in inverse correlation at some sites (Ce increases while $\mathrm{La}$ decreases). The relative contents of $\mathrm{La}, \mathrm{Ce}$, and $\mathrm{Nd}$ differ in REE phosphates of different morphological types (Fig. 1B, 2). Phosphates with the highest Ce contents form aggregates of acicular or platy particles; their interstitial space (type 1, Fig. 2) is filled with REE phosphate with lower Ce (type 2, Fig. 2). Many phosphate aggregates consist of tubes radiating from a single hollow center (type 3, Fig. 2). Monazite-halloysite aggregates of this type were found in ores from the Buranny site [7]. Their compositions plot in the middle of the trend and are similar to those of the Buranny monazites. Finally, Ce contents are the lowest in exotic REE phosphates (type 4, Fig. 2), which form compact "flowers" with a filled core. 
The behavior of $\mathrm{La}, \mathrm{Ce}$, and $\mathrm{Nd}$ in the ternary diagram is consistent with SR-XRF results, but with a greater variance (Fig. 1C). The heterogeneity appears in normalized REE spectra as variations in the magnitude and sign of the Ce anomaly. Positive Ce anomalies are most often associated with marine or soil iron-manganese concretions and result from redox variations which control oxidation state changes from $\mathrm{Ce}^{3+}$ to $\mathrm{Ce}^{4+}$.
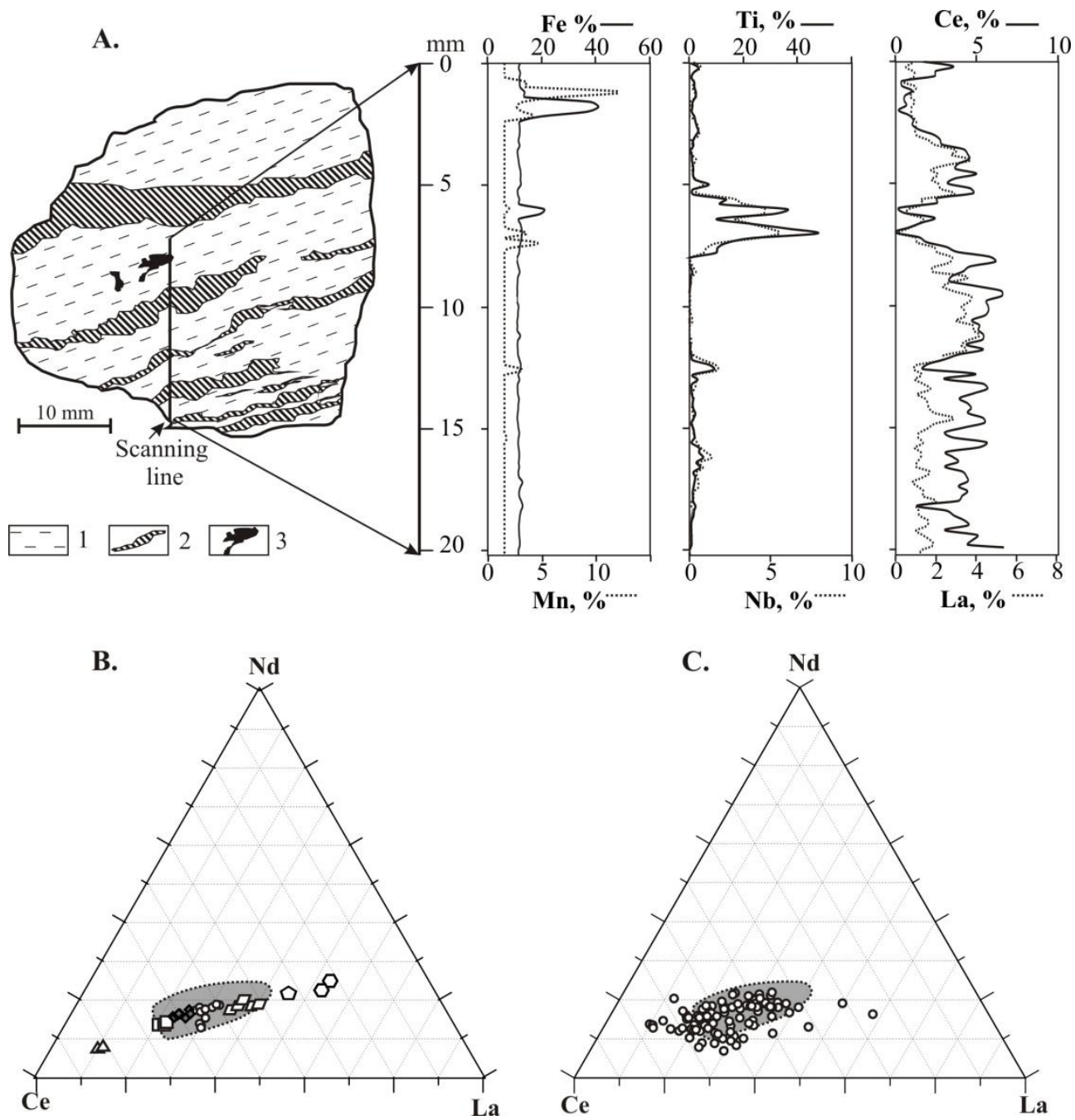

Fig. 1. A : Patterns of Fe, Mn, Ti, Nb, Ce, and La in layered REE-Nb-rich ores of the Tomtor complex (hole 308, core depth $63 \mathrm{~m}$, Yuzhny site), according to SR-XRF scanning; B: Ce, La, and Nd in REE phosphates from SEM data. 1 = material composed mainly of crandallite-group minerals, monazite (and/or rhabdophane), and goethite; 2 = layers and lenses rich in detrital material, mainly Ti oxides ; 3 = pyrite. Gray field in Ce-La-Nd ternaries shows compositions of monazites from the Buranny site. The notation in figure B corresponds to that in figure 2A.

We performed preliminary thermodynamic calculations as in $[11,12]$. Hydrous Ce, La, and $\mathrm{Nd}$ phosphates have similar stability fields in a zone (Fig. 3) within a small range of $\mathrm{pH}$ (4-6) and Eh ( $-0.25-+0.25 \mathrm{~V})$. Monazite from the Buranny ores occurs most often as 50 $\mathrm{nm}$ particles that cover halloysite tubes. Such segregations could form most likely by dehydration of a water compound or a gel. Therefore, the idea that monazite formed via a precursor phase of hydrous phosphate appears quite reasonable. 

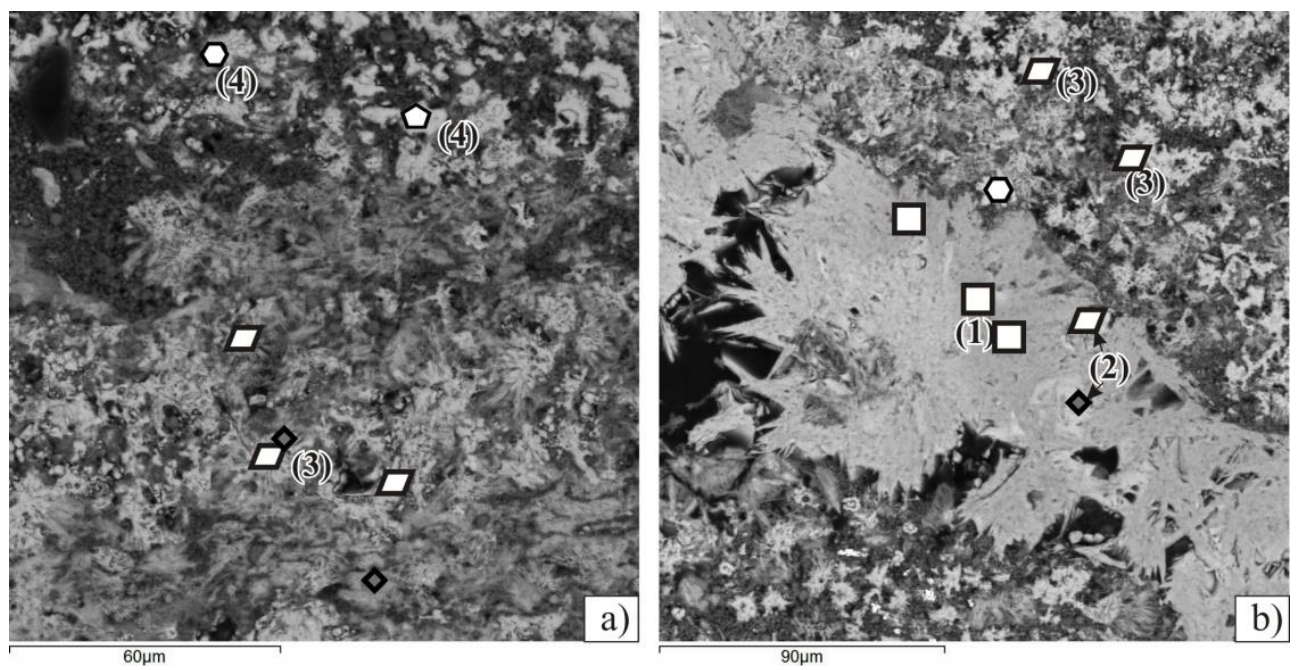

Fig. 2. REE phosphates Nb-REE ores from the Yuzhny site: b) platy and flower-like aggregates that differ in relative REE contents (hole 308, 63.0 m). Symbols in the photographs correspond to those in the ternary diagram of 1B. Numerals from 1 through 4 are different types of phosphates.
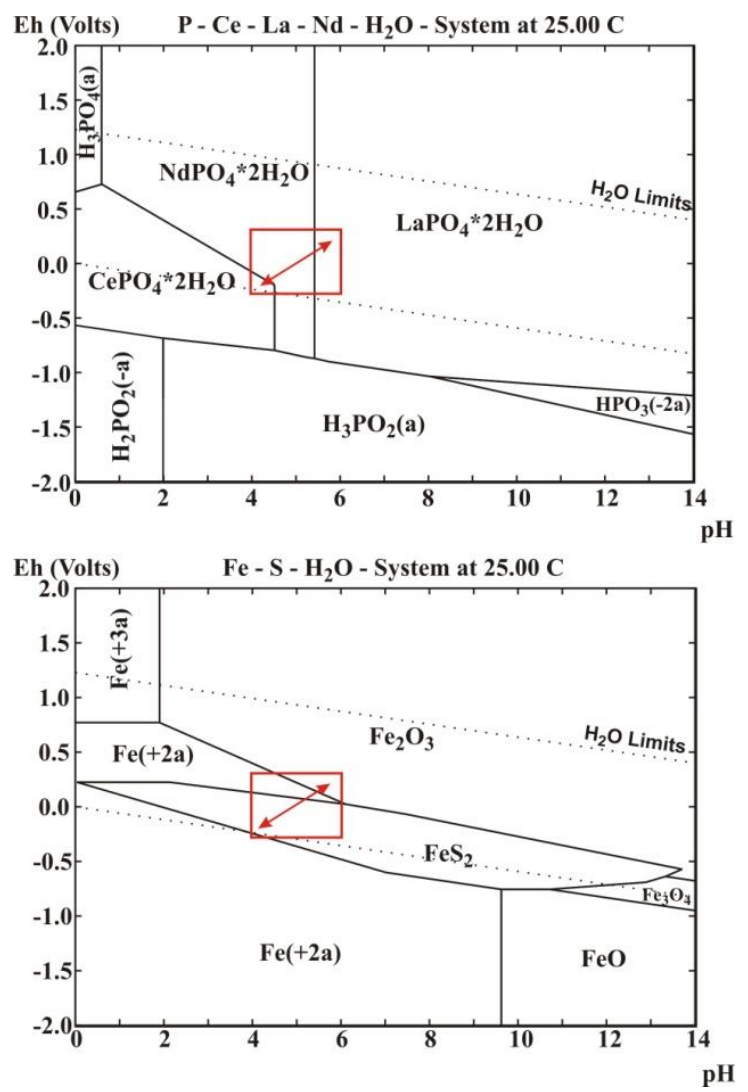

Fig. 3. Eh-pH diagrams for the $\mathrm{P}-\mathrm{Ce}-\mathrm{La}-\mathrm{Nd}-\mathrm{H}_{2} \mathrm{O}$ system at $10^{-6} \mathrm{P}, 10^{-9} \mathrm{Ce}, 10^{-9} \mathrm{La}, 10^{-9} \mathrm{Nd}$ mole at $25^{\circ} \mathrm{C}$ (left), and $\mathrm{Eh}-\mathrm{pH}$ diagrams for the $\mathrm{S}-\mathrm{Fe}-\mathrm{H}_{2} \mathrm{O}$ system at $1.44 \cdot 10^{-3} \mathrm{~S}, 2.7 \cdot 10^{-6} \mathrm{Fe}$ mole at $25^{\circ} \mathrm{C}$ (right). Red box frames presumed ore formation region. 
Assuming that ore minerals formed in near-equilibrium conditions, variations of $\mathrm{Ce}$, La and $\mathrm{Nd}$ in some coexisting mineral particles and adjacent layers can be modeled via the $\mathrm{CaPO}_{4} \cdot \mathrm{H}_{2} \mathrm{O}, \mathrm{LaPO}_{4} \cdot \mathrm{H}_{2} \mathrm{O}$ and $\mathrm{NdPO}_{4} \cdot \mathrm{H}_{2} \mathrm{O}$ stability fields, rather than in terms of the $\mathrm{Ce}$ oxidation state change. Transitions between the stability fields of different compounds depend also on $\mathrm{pH}$ and Eh (Fig. 3). This inference is supported by coexistence of minerals with different $\mathrm{Fe}$ oxidation states: goethite $\left(\mathrm{Fe}^{3+}\right)$ and pyrite $\left(\mathrm{Fe}^{2+}\right)$. As shown by our calculations, iron species may vary in the same range as calculated for REE. The absence of jarosite-group minerals in the ores indicates that $\mathrm{pH}$ could not be below 3 [13], while the absence of calcite constrains it to $\mathrm{pH} \leq 7$ [14]. These conditions are typical of an open water body in which microbial communities might have been responsible for micro-scale $\mathrm{pH}-\mathrm{Eh}$ variations evident in cooccurrence of REE phosphate varieties with different relative contents of Ce-La-Nd.

The study was supported by grant 18-17-00120 from the Russian Foundation for Basic Research.

\section{References}

1. A.R. Entin, A.I. Zaitsev, N.I. Nenashev, et al. Soviet Geol. Geoph. 12, 39 (1990)

2. S.M. Kravchenko, B.G. Pokrovsky, Econ. Geol. 90(3), 676 (1995)

3. A.V. Lapin (Ed.). Metallogeny of Carbonatite Eluvium: A Handbook. (GEOKART, GEOS, Moscow, 2011)

4. A.V. Tolstov. Principal Ore Associations of the Northern Siberian Craton (IMGRE, Moscow, 2006)

5. N.L. Dobretsov, N.P.Pokhilenko, Russ. Geol. Geoph. 51(1), 126 (2010)

6. N.V. Vladykin, A.B. Kotov, A.S. Borisenko, et al., Dokl. Earth Sci. 454(1), 7 (2014)

7. E.V. Lazareva, S.M. Zhmodik, N.L. Dobretsov, et al., Russ. Geol. Geoph. 56(6), 844 (2015)

8. A.D. Konoplev, V.I. Kuz'min, E.M. Epshtein in: The Mineralogy and Geochemistry of Placers (Nauka, Moscow, 1992)

9. M.A. Phedorin, E.L. Goldberg, Russ. Geol. Geoph. 49(1), 40 (2008)

10. HSC Chemistry 5.0. Chemical Reaction and Equilibrium Software with Extensive Thermochemical Database. ver.5.11. (Outokumpu Research Oy, Piori, Finland, 2002)

11. N.L. Dobretsov, E.V. Lazareva, S.M. Zhmodik, et al., Russ. Geol. Geoph. 56(1-2), 39 (2015)

12. E.V. Lazareva, S.M. Zhmodik, A.V. Prokopiev, N.S. Karmanov, A.I. Sergeenko, Russ. Geol. Geoph. 59, 1330 (2018)

13. O.L.Gas'kova, S.B. Bortnikova, G.P. Shironosova, Chem. Sustain. Dev. 15, 329 (2007)

14. E.V. Lazareva, N.S. Anisimova, A.V. Bryanskaya, O.L. Ogorodnikova, S.M. Zhmodik, Trans. Kronotsky State Biospheric Reserve, Mosolov, V.I. (Ed.). (Kamchatpress, Petropavlovsk-Kamchatskii, Issue 2 (2012) 